\title{
RAZVOJ SUSTAVA SANKCIJA PROTIV FIZIČKIH ILI PRAVNIH OSOBA, SKUPINA I NEDRŽAVNIH ENTITETA POVEZANIH S TERORIZMOM U OKVIRU PRAVNOG PORETKA UJEDINJENIH NARODA S ASPEKTA SUDA EUROPSKE UNIJE
}

dr. sc. Stjepan Novak*

\author{
UDK 343.326 \\ https://doi.org/10.30925/zpfsr.39.3.11 \\ Ur.: 19. travnja 2018. \\ Pr.: 3. rujna 2018. \\ Pregledni znanstveni rad
}

\begin{abstract}
Sažetak
Kao odgovor na sve učestalije, ali i pogubnije terorističke napade diljem svijeta, a osobito nakon napada na New York 11. 9. 2001., međunarodna zajednica bila je primorana, prilagoditi se i pronaći odgovarajuće rješenje. Jedan od oblika toga rješenja, odnosno borbe protiv terorizma bilo je i onemogućiti financiranje terorizma provođenjem sankcija, odnosno mjera ograničavanja protiv osoba, odnosno entiteta povezanih s terorizmom, prvenstveno zamrzavanjem imovine. Navedene mjere u velikom su broju slučajeva rezultat implementacije rezolucija Vijeća sigurnosti Ujedinjenih naroda kojima se nameću sankcije određenim fizičkim, odnosno pravnim osobama. Ovaj sustav sankcija, međutim, karakterizirao je $i$ velik broj nedostataka koji su se, uglavnom, svodili na nepoštovanje procesnih prava fizičkih, odnosno pravnih osoba prema kojima se sankcije primjenjuju. Ti nedostaci, između ostalog i pod utjecajem Suda Europske unije, s vremenom su se uklanjali, ili barem umanjivali, upravo u cilju udovoljavanja zahtjevima za što većim stupnjem zaštite prava navedenih osoba.

Ključne riječi: sustav sankcija Vijeća sigurnosti Ujedinjenih naroda, sankcije, mjere ograničavanja, Sud Europske unije, zaštita procesnih prava osoba odnosno entiteta povezanih s terorizmom.
\end{abstract}

\section{1. $U V O D$}

Cilj je ovog rada prikazati razvoj sustava sankcija usmjerenih prema fizičkim i pravnim osoba povezanim s terorizmom u okviru pravnog poretka Ujedinjenih naroda.

Ovaj sustav sankcija karakterizirao je i velik broj nedostataka koji su se,

* Dr. sc. Stjepan Novak, Ministarstvo unutarnjih poslova RH, Ulica grada Vukovara 33, Zagreb; stjepannovak@gmail.com. 
uglavnom, svodili na nepoštovanje procesnih prava fizičkih, odnosno pravnih osoba prema kojima se primjenjuju sankcije. Nedostatci, između ostalog i pod utjecajem Suda EU-a, s vremenom su se uklanjali, ili barem umanjivali, upravo radi udovoljavanja zahtjevima za što većim stupnjem zaštite prava navedenih osoba.

\section{RAZVOJ SUSTAVA SANKCIJA USMJERENIH PREMA FIZIČKIM I PRAVNIM OSOBA POVEZANIH S TERORIZMOM U OKVIRU PRAVNOG PORETKA UJEDINJENIH NARODA}

U ovom će se poglavlju, analizom relevantnih rezolucija Vijeća sigurnosti Ujedinjenih naroda (u daljnjem tekstu: VSUN), prikazati početci razvoja sustava sankcija VSUN-a usmjerenih prema fizičkim i pravnim osobama povezanih s terorizmom, izmjene tog sustava nastale pod utjecajem terorističkih napada $u$ međunarodnim razmjerima, kao i njegove daljnje izmjene u cilju poboljšanja prava osoba, odnosno entiteta prema kojima su sankcije primijenjene.

\subsection{Početci razvoja sustava sankcija usmjerenih prema fizičkim $i$ pravnim osoba povezanih s terorizmom u okviru pravnog poretka Ujedinjenih naroda}

Službeni početak sustava sankcija usmjerenih prema fizičkim i pravnim osoba povezanih s terorizmom u okviru pravnog poretka Ujedinjenih naroda, bila je Rezolucija VSUN-a 1267 (1999), ${ }^{1}$ usvojena u okviru glave VII. Povelje VSUN-a, ${ }^{2}$ donesena u povodu napada Al-Qaide na američka veleposlanstva u Tanzaniji i Keniji 1998. godine. ${ }^{3}$ Tom je Rezolucijom utemeljen Odbor $1267,{ }^{4}$ sastavljen od članica VSUN-a. Jedan od glavnih zadataka Odbora ${ }^{5}$ bio je utvrđivanje fondova i financijskih izvora povezanih s talibanima, njihovim ili s njima povezanim organizacijama, koje, potom, sve države trebaju zamrznuti. ${ }^{6} \mathrm{U}$ tom smislu određuje mjere zamrzavanja imovine, ali i zabrane putovanja (tzv. engl. travel ban) koje se sastoje u obvezi svake države da ne dopuste polijetanje s njihova teritorija ili slijetanje na njega zrakoplova u vlasništvu ili na bilo koji način povezanih s talibanima. Istom je Rezolucijom uspostavljena i posebna Lista pojedinaca ili grupa na taj način povezanih s terorizmom ${ }^{7}$ (tzv. crna

1 Vidi https://www.un.org/sc/suborg/en/sanctions/1267 (posljednji pristup ostvaren 18. 12. 2017). Za tekst Rezolucije 1267(1999), vidi http://www.un.org/ga/search/view_doc.asp?symbol=S/ RES/1267\%281999\%29 (posljednji pristup 6.7.2018.).

2 Oehmichen, A., UN-EU-Terrorist-Listing-Legal Foundations and Impacts, ZIS 9/2014, 412. (www.zis-online.com/dat/artikel/2014_9_847.pdf), (posljednji pristup 6.7.2018.). str. 414.

3 Cf. ibid., str. 412.

4 Gutherie, P., Security Council Sanctions and the Protection of Individual Rights, New York University Annual Survey of American Law, vol. 60., br. 3., 2004., str. 494; Oehmichen, op . cit. u bilj. 2., str. 414. ga naziva Odbor sankcija. Rezolucija 1267 (1999), para 6.

5 Zadatci su nabrojani u paragrafu 6. Rezolucije 1267 (1999).

6 Pedić, Ž., Odnos međunarodnoga i europskoga okvira za suzbijanje terorizma, Zagrebačka pravna revija, vol. 1, br. 1., 2012, str. 63., Rezolucija 1267 (1999), paragraf 4.

7 Oehmichen, op. cit. u bilj. 2, str. 412., Willis, G., Security Council Targeted Sanctions, Due 
lista, u daljnjem tekstu: Lista).

Rezolucijom 1333 (2000) djelovanje Odbora 1267 prošireno je na pojedince i skupine na isti način povezane s Osamom bin Ladenom i Al-Qaidom. ${ }^{8}$

Rezolucija 1363 (2001) potvrđuje prethodne rezolucije 1267 i 1333 te naglašava obvezu svih država članica Ujedinjenih naroda da u potpunosti provedu mjere određene tim rezolucijama. Nadalje, istom Rezolucijom VSUN zahtijeva da glavni tajnik, uz savjetovanje s Odborom 1267, u roku od trideset dana od njezina usvajanja uspostavi poseban mehanizam koji će, između ostalog, nadzirati implementaciju mjera određenih rezolucijama 1267 i 1333. Taj mehanizam trebao je biti zasnovan na posebnoj Nadzornoj grupi, sastavljenoj od pet članova, uključujući i predsjednika te Grupi za podršku primjenjivanja sankcija, sastavljenoj od petnaest stručnjaka iz područja borbe protiv terorizma. ${ }^{9}$ Također, potiče države da poduzmu odgovarajuće mjere, unutar vlastitih zakonodavnih i administrativnih okvira, kako bi spriječile i kaznile kršenje mjera određenih rezolucijama 1267 i 1333, kao i na izvješćivanje Odbora 1267 o svim istragama povezanim s djelovanjima koje se provode u okviru ovog režima. ${ }^{10}$

\subsection{Izmjene sustava sankcija VSUN-a pod utjecajem terorističkih napada i njegove korekcije}

U rujnu 2001. godine, nakon terorističkih napada na New York, usvojena je Rezolucija 1373 (2001), koja donosi ,sveobuhvatnu strategiju za borbu protiv međunarodnog terorizma i obvezuje države članice, pojedinačno i kolektivno, na odbijanje pružanja utočišta i financijske pomoći teroristima te na privođenje takvih osoba pravdi "11 kao i njihovo kažnjavanje. Naime, navedena Rezolucija potiče države da stvaraju vlastite „,crne liste“ te da kriminaliziraju ${ }^{12}$ svaki oblik sudjelovanja u terorističkim djelima i njihovo pomaganje. Obveze država sastoje se, nadalje, i u zamrzavanju svih fondova povezanih s osobama uključenim u terorističke aktivnosti, uskraćivanju svakog oblika financijske potpore terorističkim grupama, uskraćivanju utočišta i privođenju pravdi svake osobe povezane s počinjenjem terorističkih djela, razmjeni podataka sa svim drugim državama o grupama koje prakticiraju ili planiraju terorističke aktivnosti, kao i suradnji u istrazi, otkrivanju, izručenju i kaznenom

Process and the 1267 Ombudsperson, From the Selected Works of Grant L Willis, 2010., str. 10.

Pedić, loc. cit. Gutherie, op. cit. u bilj. 4., str. 494.

Za tekst Rezolucije 1333 (2000), vidi: http://www.un.org/ga/search/view_doc.asp?symbol=S/ RES/1333 \%282000\%29 (posljednji pristup 6.7.2018.).

9 Za tekst Rezolucije 1363 (2001), vidi: http://www.un.org/ga/search/view_doc.asp?symbol=S/ RES/1363\%20\%282001\%29 (posljednji pristup 6.7.2018.).

10 Rezolucija 1363 (2001), para 8.

11 Pedić, loc. cit.

12 Oehmichen, op. cit. u bilj. 2., str. 412. Vidi u: Derenčinović, D., Suvremeni antiterorizam na raskrižju - kaznenopravna reakcija vs. rat protiv terorizma, u: Derenčinović, D., Novi obzori suvremenog terorizma i antiterorizma, hrvatsko motrište, Pravni fakultet u Zagrebu, Akademija pravnih znanosti Hrvatske, 2007., str. 33. Za tekst Rezolucije 1373 (2001), vidi http://www. un.org/en/sc/ctc/speci almeetings/2012/docs/United\%20Nations\%20Security\%20Council\%20 Resolution\%201373\%20(2001).pdf (posljednji pristup 6.7.2018.). 
progonu osoba uključenih u takve aktivnosti. ${ }^{13}$ Nadalje, Rezolucijom je uspostavljen poseban Odbor za borbu protiv terorizma, ${ }^{14}$ sastavljen od svih članova VSUN-a, čiji je zadatak bio nadzirati provedbu ove Rezolucije.

Rezolucija 1390 (2002) još je jedan korak u međunarodnoj borbi protiv terorizma. U konkretnom slučaju, riječ je o produljivanju već postojećih mjera. U petom paragrafu Rezolucije, VSUN zahtijeva od Odbora 1267 poduzimanje određenih zadataka i izvještavanje o njima zajedno sa svojim zapažanjima. To su: 1.) ažuriranje Liste, 2.) traženje informacija od država u pogledu poduzetih radnji s ciljem provedbe mjera iz paragrafa 2., kao i drugih informacija koje Odbor 1267 smatra potrebnim, 3.) podnošenje redovitih izvješća VSUN-u o provedbi Rezolucije, 4.) hitno objavljivanje smjernica i kriterija potrebnih za olakšavanje implementacije mjera iz paragrafa 2. i 5.) činjenje svih informacija koje smatra relevantnim, uključujući i Listu, javno dostupnim putem odgovarajućih medija te 6.) suradnja s drugim relevantnim odborima VSUN-a, uključujući i Odbor iz Rezolucije 1373 (2001). ${ }^{15}$ Točke 5. i 6. poboljšavaju ono što se sustavu sankcija 1267 najviše zamjeralo. Naime, u ovakvom režimu, pojedine države mogle su predložiti uvrštavanje pojedinaca ili grupacija na Listu, a navedeni je Odbor o tomu odlučivao diskrecijskom ocjenom. Kako dotični pojedinci, odnosno grupacije nisu prethodno obaviješteni o takvom uvrštavanju na Listu, oni isto ne mogu niti spriječiti, odnosno ne mogu dokazati da bi njihovo uvrštavanje na Listu bilo nepravedno, nepravilno ili na bilo koji način neosnovano. ${ }^{16}$

Rezolucija 1452 (2002) predviđala je određene iznimke vezane na mjere predviđene dosadašnjim rezolucijama, točnije zamrzavanja imovine $\mathrm{i}$ to iz humanitarnih razloga. ${ }^{17} \mathrm{U}$ tom smislu, iznimke se odnose na sredstva potrebna za zadovoljavanje osnovnih potreba, kao što su prehrambeni troškovi, troškovi stanovanja, troškovi liječenja i medicinskih usluga, poreza, osiguranja i drugih javnih i komunalnih troškova, troškovi povezani s naknadama za pravne usluge itd., kao i izvanredni troškovi, pod uvjetom da je država zahtijevala takvu iznimku, a Odbor 1267 odobrio. $^{18}$

Rezolucija 1526 (2004), ponovno obvezuje države na provedbu rezolucija

13 Rezolucija 1373, para. 1. Vidi i mrežne stranice Security Council Counter-Terrorism Committee, https://www.un.org/sc/ctc/about-us/. Vidi i Derenčinović, D., Ogledi o terorizmu i antiterorizmu, Pravni fakultet Zagreb, 2005., str. 109. i 119.

14 CTC-Counter Terrorism Committee, odnosno Odbor za borbu protiv terorizma. Vidi i Pedić, op. cit. u bilj. 6, str. 64., fusnota 28.

15 Rezolucija 1390 (2002), para. 5. Za tekst Rezolucije 1390 (2002) vidi: http://unscr.com/en/ resolutions/doc/1390 (posljednji pristup 6.7.2018.).

16 Gutherie, op. cit. u bilj. 4, str. 513.

17 Willis, op. cit. u bilj. 7, str. 13., Pedić, op. cit. u bilj. 6, str. 64. Za tekst Rezolucije 1452 (2002) vidi: http://www.un.org/ga/search/view_doc.asp?symbol=S/RES/1452\%20\%282002\%29 (posljednji pristup 6.7.2018.).

18 Rezolucija 1452 (2002), para. 1.; Willis, G., Security Council Targeted Sanctions, Due Process and the 1267 Ombudsperson, loc. cit. 
1267 i 1333, ${ }^{19}$ produljuje primjenu dosada određenih mjera ${ }^{20}$ i poziva Odbor 1267 na poduzimanje koraka za što uspješniju provedbu rezolucija, odnosno što uspješnije provođenje naloženih mjera, ${ }^{21}$ poziva i potiče sve države i regionalne organizacije na poduzimanje odgovarajućih koraka u smislu provedbe naloženih mjera ${ }^{22}$ te podsjeća države, kao i druge međunarodne i regionalne organizacije, na dužnost ispunjavanja njihovih obveza. ${ }^{23}$

Posebno su važne, u smislu poboljšavanja sustava sankcija, odredbe iz paragrafa 17. i 18. Rezolucije. Paragrafom 17. VSUN poziva države da kad predlažu nova imena za uključivanje na Listu, daju, u najvećoj mogućoj mjeri i informacije koje dokazuju povezanost tih pojedinaca, odnosno entiteta s Osamom bin Ladenom ili članovima Al-Qaide i/ili talibanima. Odredbom paragrafa 18. VSUN snažno potiče države da, u najvećoj mogućoj mjeri, obavještavaju pojedince i entitete uključene na Listu o mjerama koje su im nametnute. ${ }^{24}$

Rezolucijom 1617 (2005), VSUN-a prvi put daje svojevrsnu definiciju „povezanosti“ s Al-Qaidom, Osamom bin Ladenom i talibanima. Iako je riječ o nejasnim kriterijima, ${ }^{25}$ oni su ipak još jedan korak prema poboljšanju sustava sankcija VSUN-a. Konkretno, sukladno danoj definiciji, povezanost uključuje: a) sudjelovanje u financiranju, planiranju, olakšavanju, pripremanju ili počinjenju djela ili aktivnosti uz, zajedno s, pod imenom, u ime ili kao potpora, b) dobavljanje, prodavanje ili prijenos oružja ili povezanog materijala, c) vrbovanje ili d) podržavanje na bilo koji drugi način djela i aktivnosti Al-Qaide, Osame bin Ladena i talibana i s njima povezanih ili iz njih proizašlih grupacija.

Posebno je važna Rezolucija 1730 (2006), kojom je VSUN nastojao utišati kritike na svoj račun zbog kršenja procesnih prava u sklopu vlastitog režima sankcija. ${ }^{26}$ Tako VSUN ovom Rezolucijom usvaja postupak brisanja s Liste te, s tim u vezi, zahtijeva od glavnog tajnika uspostavu, tzv. središnje točke, koja će primati zahtjeve za brisanje $\mathrm{s}$ Liste $\mathrm{i}$ ispunjavati druge zadatke navedene $\mathrm{u}$ aneksu Rezolucije. ${ }^{27}$

Dakle, zahtjev za brisanje s Liste podnositelji mogu podnijeti ili putem države čiji su državljani, odnosno na čijem području imaju boravište (prebivalište) ili putem središnje točke. Zadatci središnje točke detaljno su razrađeni samom Rezolucijom. ${ }^{28}$ To su zaprimanje zahtjeva i postupanje po njima, utvrđivanje je li zahtjev već podnesen te postupanje po njemu u slučaju da jest, obavješćivanje podnositelja o zaprimanju

19 Rezolucija 1526 (2004), para. 1.

Za tekst Rezolucije 1526 (2004), vidi: http://www.un.org/ga/search/view_doc.a sp?symbol=S/

RES/1526\%20\%282004\%29 (posljednji pristup 6.7.2018.).

20 Rezolucija 1526 (2004), para. 2. i 3.

21 Rezolucija 1526 (2004), para. 9-13.

22 Rezolucija 1526 (2004), para. 4. i 5.

23 Rezolucija 1526 (2004), para. 20., 22., 24.

24 Rezolucija 1526 (2004), para. 17. i 18.

25 Willis, op. cit. u bilj. 7, str. 13.

26 Willis, op. cit. u bilj. 7, str. 13. Za tekst Rezolucije 1730 (2006) vidi: http://www.un.org/ga/ search/view_doc.asp?symbol=S/RES/1730\%282006\%29 (posljednji pristup 6.7.2018.).

27 Rezolucija 1730 (2006), para. 1.

28 Rezolucija 1730 (2006), Postupak brisanja s Liste. 
zahtjeva te prosljeđivanje zahtjeva odgovarajućim državama ${ }^{29}$ kojima se preporučaju međusobne konzultacije po pitanju brisanja određenog podnositelja s Liste. Svaka od ovih država, sukladno propisanom postupku, može preporučiti brisanje s Liste, prosljeđivanjem preporuke bilo putem središnje točke, bilo izravno predsjedniku Odbora 1267, zajedno sa svojim objašnjenjima. Nakon toga, taj će Odbor odlučivati o ovom zahtjevu.

Međutim, ako se i jedna od naznačenih država usprotivi brisanju podnositelja zahtjeva s Liste, propisan je drukčiji postupak. Središnja točka će o tomu obavijestiti Odbor 1267 i pribaviti preslike zahtjeva za brisanje s Liste. Nakon proteka roka od tri mjeseca, ako niti jedna od odgovarajućih država nije dala nikakav komentar niti tražila dodatno vrijeme za njega, središnja točka će o tomu obavijestiti Odbor 1267 kojem će dostaviti i primjerke zahtjeva. Svaki član Odbora 1267 može, po savjetovanju s državama o kojima je riječ, predložiti brisanje s Liste, prosljeđivanjem zahtjeva, zajedno s objašnjenjima predsjedniku Odbora 1267. Dostatno je da samo jedan član Odbora 1267 predloži brisanje s Liste i ono će se naći na dnevnom redu istog Odbora. Ako u roku od mjesec dana niti jedan član Odbora 1267 ne predloži brisanje s Liste, zahtjev će se smatrati odbijenim te će predsjednik Odbora 1267 o tomu obavijestiti središnju točku. U svakom slučaju središnja točka će o ishodu postupka obavijestiti podnositelja zahtjeva. ${ }^{30}$

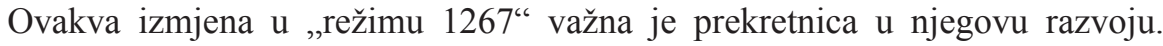
Pojedinci i entiteti stavljeni na listu dobili su mogućnost pokretanja postupka brisanja s Liste, koji su dotada mogli posredno inicirati tek podnošenjem zamolbe državi čiji su državljani ili na čijem području imaju prebivalište. Ipak, središnja točka imala je nekih ključnih nedostataka, koji još uvijek nisu omogućavali nepristran i nezavisan mehanizmu koji je sposoban ponuditi pojedincima i entitetima stavljenim na Listu učinkoviti pravni lijek, kao što je obvezujuća preporuka za VSUN ${ }^{31}$ Naime, pojedinci i entiteti stavljeni na Listu još uvijek nisu mogli biti obaviješteni o razlozima zbog kojih su stavljeni na Listu niti se očitovati o njima. Konačno, država, odnosno države koje bi, sukladno postupku propisanom Rezolucijom 1730, bojkotirale brisanje s Liste određenih pojedinaca i/ili entiteta, nisu morale objasniti razloge za to. ${ }^{32}$

I Rezolucija 1735 (2006) još je jedan važan korak k novom, poboljšanom sustavu sankcija VSUN-a. ${ }^{33}$ Među najvažnijim elementima ove Rezolucije je i zahtjev da, pri predlaganju stavljanja na Listu pojedinaca, odnosno entiteta, države podnesu detaljno izvješće koje treba uključivati: a) informacije koje dokazuju da su pojedinac, odnosno

29 To mogu biti ili države naznačene u zahtjevu ili država čiji je podnositelj državljanin ili država na čijem području ima prebivalište, odnosno boravište.

30 Rezolucija 1730 (2006), Postupak brisanja s Liste, para. 6-8.

31 Willis, op. cit. u bilj. 7, str. 14.

32 Genser, J., Barth, K., When Due Process Concerns Become Dangerous: The Security Council's 1267 Regime and the Need for Reform, Boston College International and Comparative Law Review, vol. 33., br. 1., 2010., str. 5.

33 Vidi van den Herik, L., The Security Council's Targeted Sanctions Regimes: In Need of Better protection of the Individual, Leiden Journal of International Law, vol. 20, br. 4., 2007., str. 11. Za tekst Rezolucije 1735 (2006), vidi http://www.un.org/ga/search/view_doc.asp?symbol=S/ RES/1735\%20\%282006\%29 (posljednji pristup 6.7.2018.). 
entitet povezani s terorizmom, sukladno kriterijima iz Rezolucije 1617 (2005), b) podatke o prirodi tih informacija, kao i druge dostupne podatke te c) dokumentaciju s tim u vezi. ${ }^{34}$ Nadalje, VSUN ovom Rezolucijom zahtijeva od država da kad podnesu navedeno izvješće, odrede dijelove tog izvješća koji mogu biti objavljeni, kako bi se o njemu mogli obavijestiti pojedinci, odnosno entiteti o kojima je riječ. ${ }^{35}$

Među novosti koje uvodi ova Rezolucija spada i obavješćivanje pojedinaca i entiteta o njihovu uvrštavanju na Listu. Tajništvo će, u roku od dva tjedna od dodavanja određenog imena na Listu, o tomu obavijestiti stalno predstavništvo države za koju se smatra da se na njezinu području pojedinac ili entitet o kojem je riječ nalazi, odnosno čiji je on državljanin. ${ }^{36}$

Ovoj obavijesti pridodat će se i dio izvješća o odnosnom slučaju koji je podoban za objavljivanje. Dakle, ona će obuhvaćati i sažetak razloga za uvrštavanje na Listu, ako su oni pogodni za objavljivanje. ${ }^{37}$ VSUN poziva države da, po primanju navedene obavijesti, poduzmu potrebne korake sukladno vlastitom zakonodavstvu i praksi u cilju obavještavanja o tomu pojedinaca, odnosno entiteta uvrštenih na Listu. Toj će obavijesti države pridodati i ranije spominjani dio izvješća o slučaju, podoban za objavljivanje, opis učinaka stavljanja na Listu, informacije o postupku za brisanje s Liste, kao i relevantne odredbe Rezolucije 1452 (2002). ${ }^{38}$

Rezolucijom je detaljnije uređen postupak brisanja s Liste, iako on još nije niti blizu onakvom postupku kakav bi trebao biti s gledišta zahtjeva zaštite procesnih prava. ${ }^{39}$ Naime, propisano je kako će Odbor 1267 pri razmatranju zahtjeva za brisanje s Liste posebno razmatrati je li podnositelj zahtjeva stavljen na Listu pogreškom, odnosno kao rezultat zamjene identiteta. Nadalje, razmatrat će se i jesu li još uvijek zadovoljeni kriteriji za uvrštavanje na Listu, pogotovo kriteriji određeni Rezolucijom 1617 (2005). Također, provjerit će se je li podnositelj, kada je riječ o pojedincu, preminuo, odnosno je li prekinuo sve „povezanosti“, sukladno Rezoluciji 1617 $(2005){ }^{40}$

Najvažniji dijelovi Rezolucije 1822 (2008), uz odredbe kojima se potvrđuju dosadašnji zaključci i detaljnije razrađuje postupak brisanja s Liste, ${ }^{41}$ odnose se na objavljivanje informacija povezanih s uvrštavanjem pojedinaca, odnosno entiteta na Listu, koje su pogodne za objavu te na postupak održavanja i ispitivanja Liste. Naime, VSUN je ovom Rezolucijom usmjerio Odbor 1267 da, uz pomoć Nadzornog tima i u suradnji s odgovarajućim državama članicama, učini na svojim web-stranicama dostupnim sažetak razloga za uvrštavanje na Listu odgovarajućih pojedinaca i

34 Rezolucija 1735 (2006), para. 5., Willis, op. cit. u bilj. 7, str. 15.

35 Rezolucija 1735 (2006), para. 6., Willis, loc. cit.

36 Rezolucija 1735 (2006), para. 10.

37 Willis, op. cit. u bilj. 7, 14. str.

38 Rezolucija 1735 (2006), para. 11.

39 Willis, loc. cit.

40 Rezolucija 1735 (2006), para. 14.

41 Rezolucija 1822 (2008), para. 19-22.

Za tekst Rezolucije 1822(2006), vidi http://www.un.org/ga/search/view_doc.asp?symbol=S/ RES/1822\%20\%282008\%29 (posljednji pristup 6.7.2018.). 
entiteta. ${ }^{42}$ Nadalje, dužnost je pojedine države, ako je određeni pojedinac, odnosno entitet uklonjen s Liste, u što kraćem razdoblju obavijestiti ga o tomu. Država će o tomu biti obaviještena kad se radi o njezinu državljaninu, odnosno kad se vjeruje da se pojedinac ili entitet nalaze na njezinu području. Također, VSUN je uputio Odbor 1267 da provede reviziju svih imena na Listi do 30. lipnja 2010., kako bi se osigurala njezina ažuriranost i točnost, ali i da provodi godišnju reviziju svih imena koja nisu bila revidirana u protekle tri ili više godina..$^{43}$

Dakle, sustav sankcija unutar VSUN-a, pogotovo uzevši u obzir posljednje tri rezolucije, doživio je znatne izmjene $u$ smislu njegova poboljšanja $\mathrm{s}$ aspekta zaštite procesnih prava objekata sankcija. Ipak, još uvijek nije postojalo nezavisno i nepristrano nadzorno tijelo koje bi pojedincima odnosno entitetima pogođenim sankcijama moglo omogućiti učinkovito pravno sredstvo, kako bi mogli otkloniti nametnute im sankcije.

Sljedeći korak u smjeru spomenutog razvoja bila je Rezolucija 1904 (2009). Ovom je revolucionarnom Rezolucijom uveden niz promjena, među kojima je najvažnija ustanovljavanje Ureda pravobranitelja. ${ }^{44}$ Ured je osnovan na inicijalno razdoblje od osamnaest mjeseci, kako bi pomagao Odboru 1267 u rješavanju zahtjeva za brisanje s Liste. ${ }^{45}$ Nadalje, sukladno toj Rezoluciji, dužnost je glavnog tajnika Ujedinjenih naroda da, u suradnji s Odborom 1267, imenuje eminentnog stručnjaka, visokih individualnih moralnih osobina i kvalifikacija, s iskustvom u relevantnim područjima kao što su područje ljudskih prava, borbe protiv terorizma i sankcija, za pravobranitelja, koji će svoje zadatke obavljati neovisno i nepristrano, ne primajući upute ni od jedne vlade. ${ }^{46} \mathrm{Za}$ prvog pravobranitelja imenovana je Kimberly Prost.

Dužnosti pravobranitelja određene su u Dodatku II iste Rezolucije, a među navedenim dužnostima nalaze se istraživanje zahtjeva za brisanje s Liste, prikupljanje novih podataka i njihova prezentacija Odboru 1267, vođenje dijaloga i ispitivanje podnositelja zahtjeva, izrada nacrta izvješća za Odbor 1267 koji mora sadržavati kratak sažetak glavnih argumenata koji se odnose na brisanje s Liste itd. ${ }^{47}$ Naime, kako je izrijekom propisano Rezolucijom, Ured pravobranitelja zapravo će preuzeti dužnosti središnje točke, koja će, po imenovanju pravobranitelja, zaprimati i rješavati zahtjeve pojedinaca i entiteta za brisanje s drugih lista, izvan sustava sankcija $1267 .{ }^{48}$ Među najvažnije ovlasti pravobranitelja spada analiza zahtjeva za brisanje s Liste. ${ }^{49}$

42 Rezolucija 1822 (2008), para. 13.

43 Rezolucija 1822 (2008), para. 23., 25. i 26.

44 Tünde Huber, K., Rodiles, A., An Ombudsperson in the United Nations Security Council: a Paradigm Shift?, Universidad Nacional Autónoma de México-Instituto de Investigaciones Jurídicas. Anuario Mexicano de Derecho Internacional, Décimo Aniversario, 2012, str. 109.

Za tekst Rezolucije 1904 (2009), vidi http://www.un.org/ga/search/view_doc.asp?symbol=S/ RES/1904\%282009\%29 (posljednji pristup 6.7.2018.).

$45 \mathrm{U}$ tom smislu vidi Genser, Barth, op. cit. u bilj. 32, str. 14., Eckert, S., Biersteker, T., Due Process and Target Sanctions, An Update of the Watson Report, Watson Institute for International Studies, 2012., str. 6.

46 Rezolucija 1904 (2009), para 20.

47 Eckert, Biersteker, loc. cit.

48 Rezolucija 1904 (2009), para. 21.

49 Vidi Dodatak II., para. 7c Rezolucije 1904 (2009), Willis, op. cit. u bilj. 7., str. 68. 
Ipak, instituti pravobranitelja i Ureda pravobranitelja, unatoč ostvarenom stupnju neovisnosti, na što ukazuje, između ostalog i njegovo imenovanje od strane glavnog tajnika Ujedinjenih naroda, još nisu udovoljavali osnovnim zahtjevima zaštite procesnih prava pojedinaca i entiteta stavljenih na Listu. Razlog ovome je činjenica da pravobranitelj, osim spomenute analize zahtjeva za brisanje s Liste, nije raspolagao nikakvim drugim konkretnim ovlastima niti imao poseban utjecaj na postupak brisanja s Liste. On, prema ovlastima dodijeljenim ovom Rezolucijom, nije bio ovlašten donositi bilo kakve preporuke Odboru 1267, a kamoli obvezujuće odluke u pogledu postupka brisanja s Liste pojedinaca i entiteta. ${ }^{50}$ Dakle, još uvijek nije postojalo nezavisno i nepristrano nadzorno tijelo koje bi pojedincima, odnosno entitetima pogođenim sankcijama moglo omogućiti učinkovito pravno sredstvo, kojim bi oni mogli moći otkloniti nametnute im sankcije. Isto tako, nije bilo zadovoljeno niti pravo na pristup pravosuđu, s obzirom na to da ono ima smisla jedino ako tijelo kojemu pojedinci, odnosno entiteti imaju pristup može donositi i obvezujuće odluke o njihovim pravima, u ovom slučaju, o brisanju s Liste. Ovdje to nije bio slučaj, čime se uspostavljanje instituta pravobranitelja, s ovog aspekta, zapravo činilo kao nedovršeni posao. $^{51}$

Rezolucija, nadalje, predviđa još neke važne izmjene. ${ }^{52}$ VSUN potiče države na osnivanje nacionalnih kontaktnih točaka za unošenje novih pojedinaca, odnosno entiteta na Listu. ${ }^{53}$ Zatim, uvodi novo pravilo prema kojem je detaljno izvješće o slučaju koje države moraju podnijeti Odboru 1267 pri predlaganju novih imena za Listu, na zahtjev, u cijelosti dostupno za javnost, osim onih dijelova za koje dotična država utvrdi da su povjerljivi. ${ }^{54}$ Istom Rezolucijom VSUN zahtijeva od država članica da, pri predlaganju Odboru 1267 novih imena za uvrštavanje na Listu, podnesu istom Odboru što je više moguće relevantnih informacija, pogotovo dovoljno identifikacijskih podataka, kako bi se omogućila točna identifikacija pojedinaca, odnosno entiteta. ${ }^{55}$

Nove obveze nametnute su i Odboru 1267, pa tako taj Odbor mora sažetak razloga za uvrštavanje na Listu odgovarajućih pojedinaca i entiteta učiniti javno dostupnim na svojim mrežnim stranicama u isto vrijeme kada je i ime dotičnog pojedinca, odnosno entiteta stavljeno na Listu. ${ }^{56} \mathrm{~S}$ tim u vezi, VSUN je Rezolucijom pozvao sve članove Odbora 1267 i Nadzornog tima da s njim podijele sve dostupne informacije koje imaju o zahtjevima za uvrštavanje na Listu, podnesenim od država članica, koje bi mogle koristiti tom odboru za donošenje odluke. ${ }^{57}$

Također, VSUN je zatražio od Odbora 1267 da produlji rok u kojem članovi Odbora moraju potvrditi imena predložena za uvrštavanje na Listu, ${ }^{58}$ ali i da isti Odbor

50 Willis, op. cit. u bilj. 7, str. 69. i 70.

51 Tünde Huber, Rodiles, op. cit. u bilj. 44, str. 140.

52 Cf. ibid., str. 128.

53 Rezolucija 1904 (2009), para. 8.

54 Rezolucija 1904 (2009), para. 11.

55 Rezolucija 1904 (2009), para. 13.

56 Rezolucija 1904 (2009), para. 14.

57 Rezolucija 1904 (2009), para. 16.

58 Rezolucija 1904 (2009), para. 17., Tünde Huber, Rodiles, op. cit. u bilj. 44, str. 128, navode 
osigura da njegovi članovi pruže razloge za svoje eventualno protivljenje brisanja s Liste određenih pojedinaca, odnosno entiteta, kada je ovakav postupak pokrenut. ${ }^{59}$

Uslijedila je i još jedna izmjena u pogledu rokova za postupanje. Glavni tajnik će, u roku od tri dana od dodavanja određenog imena na Listu, o toj činjenici obavijestiti stalno predstavništvo države za koju se smatra da se pojedinac ili entitet o kojem je riječ, nalazi na njezinu području, odnosno kada je riječ o pojedincu, države čiji je državljanin. ${ }^{60}$ Isti se rokovi primjenjuju i za slučaj brisanja s Liste. Te će države, pravodobno i sukladno vlastitim propisima, o tomu obavijestiti dotičnog pojedinca. ${ }^{61}$

Pozivajući se na relevantne odredbe Rezolucije 1822 (2008), VSUN naglašava zahtjev da sve države moraju poduzeti sve potrebne mjere, sukladno svojim zakonodavstvima, kako bi na vrijeme obavijestile pojedinca, odnosno entitet o njihovu stavljanju na Listu, kao i da toj obavijesti moraju priključiti sažetak razloga za uvrštavanje na Listu, opis učinaka uvrštavanja na Listu, postupak Odbora 1267 za razmatranje brisanja s Liste, uključujući i mogućnost podnošenja takvog zahtjeva pravobranitelju, sukladno relevantnim odredbama ove Rezolucije te odredbe o iznimkama iz Rezolucije 1452 (2002). ${ }^{62}$ Nadzorni je tim dužan Odboru 1267 svakih šest mjeseci dostavljati popis pojedinaca s Liste koji su navodno pokojni s drugim relevantnim podatcima s tim u vezi, kako bi se osigurala točnost i ažuriranost Liste. ${ }^{63}$ Konačno, VSUN i dalje inzistira na obvezama Nadzornog tima, u smislu godišnjih revizija Liste, odnosno pojedinaca i entiteta unesenih na nju. ${ }^{64}$

Rezolucija 1988 (2011) razdvojila je režim sankcija prema pojedincima, odnosno entitetima povezanim s talibanima od režima sankcija prema pojedincima, odnosno entitetima povezanim s Al-Qaidom. Točnije, uspostavljen je nov sustav sankcija za pojedince $\mathrm{i}$ entitete povezane $\mathrm{s}$ talibanima $\mathrm{s}$ posebnim zadatcima određenim $\mathrm{u}$ tom smislu, ${ }^{65}$ čije je djelovanje produljeno rezolucijama 2082 (2012) i 2160 (2014). ${ }^{66}$

Rezolucija 1989 (2011), osim što se bavila i nekim strukturalnim promjenama s obzirom na svoju prethodnicu, uključujući i promjenom naziva Liste Odbora 1267, čiji službeni naziv postaje Lista sankcija Al-Qaide, ${ }^{67}$ ojačala je položaj pravobranitelja.

produljenje s pet na deset dana.

59 Rezolucija 1904 (2009), para. 25.

60 Rezolucija 1904 (2009), para. 18.

61 Rezolucija 1904 (2009), para. 27.

62 Rezolucija 1904 (2009), para. 19.

63 Rezolucija 1904 (2009), para. 26.

64 Rezolucija 1904 (2009), para. 28.-32.

65 Rezolucija 1988 (2011), para. 30.

Za tekst Rezolucije 1988 (2011), vidi: http://www.un.org/ga/search/view_doc.asp?symbol=S/ RES/1988\%20\%282011\%29 (posljednji pristup 6.7.2018.).

66 Mrežne stranice VSUN-a, http://www.un.org/sc/committees/1988/; između ostalog, naglašena je i potreba suradnje Afganistanaca koji rade u cilju mira i pomirenja i Vijeća sigurnosti (preambula) te država s Interpolom (Dodatak, para x.). Za tekst Rezolucije 2082(2012) vidi http://www.un.org/ga/search/view_doc.asp?symbol=S/RES/2082\%20\%282012\%29 (posljednji pristup 6.7.2018.). Za tekst Rezolucije 2160 (2014), vidi http://www.un.org/en/ga/ search/view_doc.asp?symbol=S/RES/2160\%282014\%29. (posljednji pristup 6.7.2018.).

67 Rezolucija 1989 (2011), para 1., Eckert, Biersteker, op. cit. u bilj. 45, str. 7. Za tekst Rezolucije 1989 (2011) vidi: http://www.un.org/ga/search/view_doc.asp?symbol=S/RES/1989\%20 $\% 282011 \% 29$ (posljednji pristup 6.7.2018.). 
Osim što mu je mandat produljen za osamnaest mjeseci, određeno je da će pravobranitelj donositi preporuke o brisanju pojedinaca, odnosno entiteta s Liste ili o njihovu zadržavanju na njemu. ${ }^{68}$ Ovakve preporuke još uvijek nemaju obvezujuću snagu, ali se ne može reći da su bez ikakve snage. Naime, ako pravobranitelj Odboru 1267 preporuči brisanje određenog pojedinca, odnosno entiteta s Liste, a u roku od šezdeset dana taj Odbor jednoglasno ne odluči zadržati ga na Listi ili ne proslijedi pitanje na odlučivanje VSUN-a, taj će se pojedinac, odnosno entitet brisati s Liste. ${ }^{69}$ Nadalje, sve se države potiču da u ovom postupku, u što kraćem roku, dostave pravobranitelju sve relevantne podatke, po mogućnosti, tamo gdje je to primjereno, i povjerljive podatke. S druge strane, potvrđuje se da će pravobranitelj s takvim podatcima postupati sukladno ograničenjima koja je odredila dotična država ${ }^{70}$ te takve podatke neće otkrivati bez pisane suglasnosti te države ni u jednoj fazi prikupljanja informacija i vođenja dijaloga sukladno Rezoluciji. ${ }^{71}$ Također, snažno se potiču države koje su tražile uvrštavanje na Listu da pravobranitelju dopuste da otkrije njihov identitet podnositelju zahtjeva za brisanje s Liste. ${ }^{72}$

Upućuje se Odbor 1267 da nastavi razmatrati zahtjeve država za brisanje s Liste pojedinaca, odnosno entiteta koji navodno više ne zadovoljavaju kriterije za ostajanje na Listi, ali se potiču i države članice da same podnose zahtjeve za brisanje s Liste kada više ne postoje uvjeti za ostajanje na njemu. ${ }^{73}$ Zanimljivo je i da se Rezolucijom potvrđuje da države moraju posebno naglasiti, Odboru 1267 ili pravobranitelju, ako žele da njihov identitet kao država predlagatelja uvrštavanja određenih pojedinaca, odnosno entiteta ostane tajan. ${ }^{74}$

Isto tako, važan korak je učinjen i u poboljšanju ostvarivanja prava na pristup pravosuđu. Naime, postupak brisanja s Liste, i zadaće s tim u vezi, pravobranitelj će obavljati na temelju zahtjeva koji je predao pojedinac, odnosno entitet koji želi postići brisanje s Liste ili u njegovo ime. To mogu, dakle, učiniti ili oni sami ili putem svojih pravnih predstavnika. ${ }^{75}$

Rezolucija 2083 (2012) produljuje mandat pravobranitelja za trideset mjeseci te se u njoj ponavljaju raniji zaključci, ciljevi i zadatci. Nadalje, odlučeno je da ako pravobranitelj ne može ispitati podnositelja zahtjeva za brisanje s Liste u državi njegova prebivališta, odnosno boravišta, pravobranitelj može zahtijevati da Odbor 1267 razmotri mogućnost privremenog izuzeća od primjene sankcija zamrzavanja imovine i zabrane putovanja podnositelja, kako bi on mogao snositi troškove putovanja i doputovati u državu gdje bi ga pravobranitelj mogao ispitati. Trajanje ovog izuzeća

68 Rezolucija 1989 (2011), 68., para. 21.

69 Rezolucija 1989 (2011), para. 23., Eckert, Biersteker, op. cit. u bilj. 45, str. 7; isti se postupak provodi i kad država podnese zahtjev za brisanje s Liste, sukladno para 27.

70 Rezolucija 1989 (2011), para. 25.

71 Rezolucija 1989 (2011), Dodatak II, (g).

72 Rezolucija 1989 (2011), para. 29.

73 Rezolucija 1989 (2011), para. 30. i 31.

74 Rezolucija 1989 (2011), para. 14.

75 Kokott, J., Sobotta, C., The Kadi Case-Constitutional Core Values and International LawFinding the Balance, The European Journal of International Law, vol. 23., br. 4, 2012., str. 1021. 
treba se svesti samo na onoliko koliko je nužno potrebno da dotični podnositelj zahtjeva sudjeluje u navedenom postupku ispitivanja. Do ovakvog izuzeća, dakle, može doći na zahtjev pravobranitelja te uz pristanak podnositelja zahtjeva, kao i države u koju bi podnositelj trebao otputovati i svih tranzitnih država. ${ }^{76}$

Rezolucijom 2161 (2014) produljen je mandat pravobranitelja, kao i Nadzornog tima za trideset mjeseci, dakle do prosinca 2017. godine. Također, poduzeti su i još neki koraci prema ostvarivanju većeg stupnja procesne zaštite pojedinaca, odnosno entiteta stavljenih na Listu. Tako je određeno kako se u pojedinim slučajevima konsenzusom može skratiti rok od šezdeset dana u kojem Odbor 1267 treba jednoglasno odlučiti o zadržavanju pojedinca, odnosno entiteta na Listi ili proslijediti pitanje na odlučivanje VSUN-u, inače će doći do njegova brisanja s Liste. ${ }^{77}$

I nakon opisanih promjena sustav sankcija VSUN-a 1267 našao se na meti kritika. U tom kontekstu, treba spomenuti Koaliciju država istomišljenica ${ }^{78}$ koja je podnijela svoje preporuke tijekom $2011 . .^{79}$ i 2012. godine.$^{80}$ Pohvalivši dosadašnji napredak VSUN-a, pogotovo uspostavu institucije pravobranitelja, iznijele su i nove preporuke u vidu pojačane transparentnosti postupaka brisanja s Liste, neograničeno produljenje mandata pravobranitelja, pojačane suradnje pravobranitelja i država u prikupljanju podataka, povećanja dosega nadležnosti pravobranitelja i drugih koraka koji bi doprinijeli još višem stupnju zaštite procesnih prava pojedinaca, odnosno entiteta na koje su usmjerene sankcije VSUN-a.

Slično, i 2014. godine, ova je skupina država iznijela prijedloge za poboljšanje sustava sankcija $1267 .{ }^{81}$ Riječ je bila o: a) zahtjevu da mandat pravobranitelja bude stalan, što bi pridonijelo kredibilitetu njegova rada, b) zahtjevu za poboljšanjem razmjene podataka između država i pravobranitelja, kao i Odbora 1267 te nacionalnih i regionalnih sudova i drugih vlasti, c) zahtjevu za većim stupnjem transparentnosti, u smislu da svaka odluka mora sadržavati razloge, koji, jednako kao i izvješća pravobranitelja, moraju biti objavljeni, vodeći računa o zaštiti privatnosti i povjerljivih podataka i d) zahtjevu da Odbor 1267 nastavi provoditi, tzv. trogodišnji nadzor (nadzor imena koja nisu bila revidirana posljednje tri ili više godina) te da, u slučaju zadržavanja dotičnih imena na Listi, o tomu bude donesena obrazložena odluka, kao i da ako nadzor nije proveden unutar ovoga trogodišnjeg razdoblja do brisanja s Liste dolazi automatizmom.

Vidljivo je da se sustav sankcija VSUN-a znatno razvijao u posljednjih

76 Rezolucija 2083 (2012), para 36. Za tekst Rezolucije 2083 (2012) vidi: http://www.un.org/ga/ search/view_doc.asp?symbol=S/RES/2083\%282012\%29 (posljednji pristup 6.7.2018.).

77 Rezolucija 2161 (2014), para 51. Za tekst Rezolucije 2161 (2014) vidi: http://unscr.com/en/ resolutions/doc/2161 (posljednji pristup 6.7.2018.).

78 Eckert, Biersteker, op. cit. u bilj. 45., str. 11.

79 Dokument Koalicije država istomišljenica, vidi http://www.news.admin.ch/NSBSubscriber/ message/attachments/22759.pdf (posljednji pristup 6.7.2018.).

80 Službene stranice knjižnice Dag Hammarskjöld UN-a http://repository.un.org/ handle/11176/17748 (posljednji pristup 6.7.2018.).

81 Stranice Stalnog predstavništva Norveške u UN-u (Norway in the UN, Permanent Mission to the United Nations in New York) http://www.norway-un.org/Statements/Security-Council/SCSecurity-Council-working-methods---targeted-sanctions/\#.VffqXG7bVec (posljednji pristup 6.7.2018.). 
petnaestak godina te mijenjao u smislu formiranja instituta koji su trebali rezultirati što većim stupnjem zaštite prava osoba, odnosno entiteta prema kojima se primjenjuju sankcije.

\subsection{Prikaz razvoja sustava sankcija VSUN-a usmjerenih prema fizičkim i pravnim osoba povezanih s terorizmom}

Ključni trenutci razvoja sustava sankcija usmjerenih prema fizičkim i pravnim osoba povezanih s terorizmom u okviru pravnog poretka Ujedinjenih naroda moguće je prikazati i u tablici:

\begin{tabular}{|l|l|}
\hline Rezolucija 1267 (1999) & Osnivanje Odbora 1267 sa zadatkom formiranja i ažuriranja Liste \\
\hline Rezolucija 1333 (2000) & $\begin{array}{l}\text { Djelovanje Odbora } 1267 \text { prošireno je na pojedince i skupine povezane } \\
\text { s Osamom bin Ladenom i Al-Qaidom }\end{array}$ \\
\hline Rezolucija 1363 (2001) & $\begin{array}{l}\text { Poticanje država da poduzmu odgovarajuće mjere, unutar vlastitih } \\
\text { zakonodavnih i administrativnih okvira, kako bi spriječile i } \\
\text { kaznile kršenje mjera određenih rezolucijama 1267 i 1333, kao } \\
\text { i na izvješćivanje Odbora 1267 o svim istragama povezanim s } \\
\text { djelovanjima koje se provode u okviru ovog režima. }\end{array}$ \\
\hline Rezolucija 1373 (2001) & $\begin{array}{l}\text { Donošenje sveobuhvatne strategije za borbu protiv međunarodnog } \\
\text { terorizma te obvezuje države članice, pojedinačno i kolektivno, na } \\
\text { odbijanje pružanja utočišta i financijske pomoći teroristima te na } \\
\text { privođenje takvih osoba pravdi }{ }^{82} \text { kao i njihovo kažnjavanje. }\end{array}$ \\
\hline Rezolucija 1390 (2002) & $\begin{array}{l}\text { Isticanje potrebe za većim stupnjem transparentnosti u djelovanju } \\
\text { Odbora 1267. }\end{array}$ \\
\hline Rezolucija 1452 (2002) & $\begin{array}{l}\text { Predviđanje određenih iznimki od primjene mjera iz prethodnih } \\
\text { rezolucija radi omogućavanja zadovoljavanja osnovnih potreba } \\
\text { sankcioniranih osoba. }\end{array}$ \\
\hline Rezolucija 1526 (2004) & $\begin{array}{l}\text { Produljenje primjene do sada određenih mjera }{ }^{83} \text { i pozivanje Odbora } \\
\text { 1267 na poduzimanje koraka s ciljem što uspješnije provedbe } \\
\text { rezolucija, odnosno provođenja njima naloženih mjera }{ }^{84} \text { pozivanje } \\
\text { i poticanje svih država i regionalnih organizacija na poduzimanje } \\
\text { odgovarajućih koraka u provedbi naloženih mjera } \\
\text { država, kao i drugih medsjećanje } \\
\text { ispunjavanje njihovih obveza. }\end{array}$ \\
\hline Rezolucija 1566 (2004) & $\begin{array}{l}\text { Isticanje ranijih zaključaka VSUN-a te pozivanje i država i drugih } \\
\text { tijela unutar sustava sankcija VSUN-a na poduzimanje odgovarajućih } \\
\text { mjera u cilju borbe protiv terorizma. }\end{array}$ \\
\hline Rezolucija 1617 (2005) & $\begin{array}{l}\text { Definiranje ,povezanosti“ s terorističkim organizacijama i njihovim } \\
\text { vođama (Al-Qaidom, bin Ladenom i talibanima). }\end{array}$ \\
\hline
\end{tabular}

82 Pedić, op. cit. u bilj. 6, str. 63. Vidi Derenčinović, op. cit. u bilj. 13.

83 Rezolucija 1526 (2004), para. 2. i 3.

84 Rezolucija 1526 (2004), para. 9-13.

85 Rezolucija 1526 (2004), para. 4. i 5.

86 Rezolucija 1624 (2005), para 6. Za tekst Rezolucije 1624 (2005) vidi http://unscr.com/en/ resolutions/doc/1624 (posljednji pristup 6.7.2018.). 


\begin{tabular}{|c|c|}
\hline Rezolucija 1624 (2005) & $\begin{array}{l}\text { Uspostavljanje dodatne suradnje između država i Odbora za borbu } \\
\text { protiv terorizma, uspostavljenog Rezolucijom } 1373 \text { (2001), koja bi } \\
\text { uključivala dijalog i razmjenu informacija }{ }^{86} \text { te ponovno ističe obveze } \\
\text { država da sudjeluju u borbi protiv terorizma }\end{array}$ \\
\hline Rezolucija 1699 (2006) & $\begin{array}{l}\text { Zahtjev prema glavnom tajniku da poveća stupanj suradnje između } \\
\text { Ujedinjenih naroda i Interpola. }\end{array}$ \\
\hline Rezolucija 1730 (2006) & $\begin{array}{l}\text { Formiranje „središnje točke“ za zaprimanje zahtjeva za brisanje s } \\
\text { Liste. }\end{array}$ \\
\hline Rezolucija 1735 (2006) & $\begin{array}{l}\text { Poboljšanje sustava sankcija VSUN-a dodatnim zahtjevima u pogledu } \\
\text { izvješća država članica pri predlaganju stavljanja na Listu pojedinaca, } \\
\text { odnosno entiteta, kao i obavješćivanja pojedinaca, odnosno entiteta } \\
\text { o tomu. }\end{array}$ \\
\hline Rezolucija 1822 (2008) & $\begin{array}{l}\text { Objava na mrežnim stranicama Odbora } 1267 \text { sažetka razloga za } \\
\text { uvrštavanje na Listu odgovarajućih pojedinaca i entiteta }\end{array}$ \\
\hline Rezolucija 1904 (2009) & Osnivanje Ureda pravobranitelja. \\
\hline Rezolucija 1988 (2011) & $\begin{array}{l}\text { Razdvajanje režima sankcija prema pojedincima, odnosno entitetima } \\
\text { povezanim s talibanima od režima sankcija prema pojedincima, } \\
\text { odnosno entitetima povezanim s Al-Qaidom }\end{array}$ \\
\hline Rezolucija 1989 (2011) & $\begin{array}{l}\text { Ovlašćivanje pravobranitelja na donošenje preporuka o brisanju } \\
\text { pojedinaca, odnosno entiteta s Liste ili o njihovu zadržavanju na } \\
\text { njemu; promjena službenog naziva Liste u „Sankcijska lista za Al- } \\
\text { Qaidu“. }\end{array}$ \\
\hline Rezolucija 2083 (2012) & Produljenje mandata pravobranitelja za trideset mjeseci. \\
\hline Rezolucija 2161 (2014) & $\begin{array}{l}\text { Produljenje mandata pravobranitelja i ostvarivanje većeg stupnja } \\
\text { procesne zaštite pojedinaca, odnosno entiteta stavljenih na Listu. }\end{array}$ \\
\hline Rezolucija 2170 (2015) & $\begin{array}{l}\text { Nametanje sankcija šestorici pojedinaca povezanih s Al-Kaidom, } \\
\text { ISIL-om i Al Nusrah Frontom. }\end{array}$ \\
\hline Rezolucija 2178 (2015) & $\begin{array}{l}\text { Poticanje država članica na daljnje mjere u sprečavanju i pomaganju } \\
\text { terorizma. }\end{array}$ \\
\hline Rezolucija 2253 (2015) & $\begin{array}{l}\text { Uključivanje osoba, odnosno entiteta povezanih s Islamskom } \\
\text { Državom (ISIL) na Listu. }\end{array}$ \\
\hline Rezolucija 2368 (2017) & $\begin{array}{l}\text { Potvrđivanje dosadašnjih mjera, poticanje država na suradnju u borbi } \\
\text { protiv terorizma i razmjenu podataka. }\end{array}$ \\
\hline
\end{tabular}

Tablica 1.: Važnije rezolucije i njima uvedene promjene unutar sustava sankcija VSUN-a protiv osoba, odnosno entiteta povezanih s terorizmom.

Sukladno prikazanom, možemo ukratko opisati kako danas izgleda postupak uvrštavanja odnosno brisanja s Liste.

Zahtijevati uvrštavanje određene osobe, odnosno entiteta na Listu mogu sve države članice Ujedinjenih naroda. Pri podnošenju ovog zahtjeva, koji se podnosi na posebnom obrascu, države trebaju podnijeti i detaljno izvješće koje, između ostalog, treba uključivati razloge koji opravdavaju uvrštavanje na Listu, podatke o njihovim aktivnostima, povezanosti s drugim osobama koje se nalaze na Listi, dokaze o istim navodima i druge podatke, s ciljem dokazivanja opravdanosti stavljanja dotičnih osoba na Listu. Također, izvješće mora sadržavati što više identifikacijskih podataka 
o osobama, odnosno entitetima čije se uvrštavanje predlaže na Listu.

Ako Odbor 1267 o zahtjevu ne odluči u roku od deset radnih dana, obavijestit će državu predlagateljicu o fazi u kojoj se njezin zahtjev nalazi.

Kad zahtjev bude usvojen, istodobno s uvrštavanjem imena na Listu, Odbor 1267 na svojoj će mrežnoj stranici objaviti i sažetak razloga za uvrštavanje dotične osobe, odnosno entiteta na Listu. Također, odmah po usvajanju zahtjeva, o tomu će obavijestiti stalno predstavništvo države za koju se smatra da se na njezinu području osoba ili entitet o kojem je riječ nalazi, odnosno čije ima državljanstvo. ${ }^{87}$

Zahtijevati brisanje osoba, odnosno entiteta s Liste mogu osoba, odnosno entitet o kojem je riječ ili države članice Ujedinjenih naroda. Osoba, odnosno entitet o kojem je riječ može zahtjev podnijeti sam, putem predstavnika ili putem Ureda pravobranitelja. Država članica može biti ona koja je uvrštavanje na Listu predložila, ali i bilo koja druga. Zahtjev treba sadržavati objašnjenje zbog kojeg podnositelj smatra da uvjeti za zadržavanje dotične osobe, odnosno entiteta nisu više zadovoljeni.

Postupak Odbora 1267 razlikuje se ovisno o kojem je podnositelju riječ. Ako je riječ o državi članici koja je predložila uvrštavanje te osobe, odnosno entiteta na Listu, tada će se dotična osoba, odnosno entitet brisati u roku od šezdeset dana ako taj Odbor jednoglasno ne odluči zadržati ga na Listi ili ne proslijedi pitanje na odlučivanje VSUN-a. Ako je riječ o drugoj državi članici, Odbor 1267 odluku donosi na uobičajeni način, odnosno konsenzusom.

U slučajevima gdje pravobranitelj preporuči zadržavanje osobe, odnosno entiteta na Listi, ta se osoba odnosno entitet neće brisati s Liste. Ako pravobranitelj preporuči brisanje s Liste, tada će se ime dotične osobe, odnosno entiteta brisati $u$ roku od šezdeset dana ako Odbor 1267 jednoglasno ne odluči zadržati ga na Listi ili ne proslijedi pitanje na odlučivanje VSUN-u. ${ }^{88}$

Opisani sustav sankcija VSUN-a u današnjem obliku rezultat je, između ostalog, i kritika Suda EU-a koje je upućivao u svojim presudama.

Tako je u presudi Kadi II Sud konstatirao da, bez obzira na postojanje središnje točke, ostaje činjenica da je postupak pred Odborom 1267 u biti diplomatskog i međuvladinoga karaktera, a osobe i subjekti u pitanju nemaju stvarnu mogućnost dokazati svoja prava ${ }^{89}$

Po donošenju ove presude, došlo je do donošenja spomenutih rezolucija, u pogledu formiranja Ureda pravobranitelja i postupnog jačanja njegovih ovlasti.

Međutim, u predmetu Kadi III, Opći sud je smatrao da sve ono što je naveo Sud u predmetu Kadi II u odnosu na središnju točku zapravo vrijedi i za Ured pravobranitelja. Naveo je, naime, kako VSUN još uvijek nije ustanovio nezavisno i

87 United Nations Security Council, Subsidiary Organs, Security Council Committee pursuant to resolutions 1267 (1999) 1989 (2011) and 2253 (2015) concerning ISIL (Da'esh) Al-Kaida and associated individuals groups undertakings and entities. Vidi na https://www.un.org/sc/suborg/ en/sanctions/1267/aq_sanctions_list/procedures-for-listing (posljednji pristup 18. 12. 2017.).

88 Ibid., https://www.un.org/sc/suborg/en/sanctions/1267/aq_sanctions_list/procedures-fordelisting (posljednji pristup 11. 4. 2018.).

89 Presuda od 3. 9. 2008. Yassin Abdullah Kadi i Al Barakaat International Foundation protiv Vijeća Europske unije i Komisije Europskih zajednica, spojeni predmeti C-402/05 P i C-415/05, ECLI:EU:C:2008:461 (dalje u tekstu Kadi II), para. 323. 
nepristrano tijelo nadležno za saslušanje i odlučivanje o tužbama protiv pojedinačnih odluka Odbora 1267. Zbog navedenih razloga, Opći sud nije smatrao da je činjenica osnivanja Ureda pravobranitelja rezultirala takvim promjenama koje bi se mogle tumačiti kao zadovoljavanje uvjeta postavljenih u predmetu Kadi II. ${ }^{90}$

S obzirom na i dalje postojeće kritike, vrlo je izgledan i daljnji razvoj sustava sankcija VSUN-a.

\section{PRIRODA SANKCIJA VSUN-A}

Pitanje pravne prirode sankcija VSUN-a svodi se na pitanje je li riječ o građanskim, odnosno administrativnim sankcijama ili kaznenim. Ovo je važno jer o tomu ovisi i stupanj zaštite procesnih prava koja se treba jamčiti osobama, odnosno entitetima na koje se sankcije odnose.

VSUN je u Rezoluciji 1735 (2006) te u Rezoluciji 1989 (2011) izrijekom ustvrdio da su mjere o kojima je riječ preventivne naravi, neovisne o kaznenim standardima utvrđenim u nacionalnim pravima..$^{91}$

U presudi predmeta Kadi II, Sud EU-a definirao je mjere zamrzavanja imovine kao privremenu mjeru opreza, ${ }^{92}$ a na isti zaključak nailazi se i u drugim presudama Suda EU-a. ${ }^{93}$ Opći sud u presudi Kadi III ponovno je otvorio ovo pitanje, ${ }^{94}$ a nešto drukčije mišljenje imali su nezavisni odvjetnik Bot i Sud u presudi Kadi IV.

Nezavisni odvjetnik Bot zaključio je da je Opći sud bio u zabludi kad je doveo

90 Presuda od 30. 9. 2010. Yassin Abdullah Kadi protiv Europske komisije, T-85/09, ECLI:EU:T:2010:418 (dalje u tekstu Kadi III), para. 128.; Oehmichen, op . cit. u bilj. 2, str. 418.; Kokott, Sobotta, op. cit. u bilj. 75, str. 1020. Marguiles, smatra kako sustav, nakon uvođenja pravobranitelja funkcionira te kritizira činjenicu da Sud, u predmetu Kadi IV, to nije primijetio. Marguiles, P., Aftermath of an Unwise Decision: The U.N. Terrorist Sanctions Regime After Kadi II, Amsterdam Law Forum, vol. 6, br. 2., 2014. Vidi i Ginsborg, L., Scheinin M:, You Can't Always Get What You Want: The Kadi II Conundrum and the Security Council 1267 Terrorist Sanctions Regime, Essex Human Rights Review, vol. 8, br. 1, 2011, Special Issue on Balancing Counter-Terrorism Efforts with Human Rights a Decade After 9/11, str. 19.

91 Rezolucija 1735 (2006), preambula, Rezolucija 1989 (2011), preambula. Third Report of the Analytical Support and Sanctions Monitoring Team Appointed pursuantto Resolution 1526 (2004) concerning Al-Kaida and the taliban and Association Individuals and Entities, para. 4142, U.N. Doc. S/2005/572 (9 September 2005). Vidi Genser, Barth, op. cit. u bilj. 32. i Ghasem Zamani, S., Mazaheri J., The Need for International Judicial Review of UN Economic Sanctions u: Marossi, Z. A., Bassett M. R. Economic Sanctions under International Law, T.M.C. Asser press, 2015., str. 224.

92 Kadi II, op. cit. u bilj. 89, para. 358.

93 Presuda od 5. 11. 2014., Adib Mayaleh protiv Vijeća Europske unije, spojeni predmeti T307/12 i T408/13, ECLI:EU:T:2014:926. (u daljnjem tekstu: Mayelah), para. 175. Vidi i Presuda od 12. 12. 2006. Organisation des Modjahedines du people d'Iran protiv Vijeća Europske unije, T-228/02 ECLI:EU:T:2006:384, para. 71. Presuda od 15. 11. 2012., Stichting Al-Aqsa i Nizozemska Kraljevina protiv Vijeća Europske unije, C-539/10 P i 550/10 P, ECLI:EU:C:2012:711, para. 120., Presuda od 11. 7. 2007., Jose Maria Sison protiv Vijeća Europske unije, T-47/03 DEP, ECLI:EU:T:2007:207., para. 101.

94 Kadi III, op. cit. u bilj. 90, para. 150. 
u pitanje preventivnu prirodu mjera zamrzavanja imovine. ${ }^{95} \mathrm{U}$ tom smislu možemo istaknuti i zaključak Suda u predmetu Kadi $I V$, prema kojem, usprkos njihovoj preventivnoj naravi, predmetne restriktivne mjere negativno utječu na slobode i prava osoba prema kojima se primjenjuju, uz znatno narušavanje njihova profesionalnog $\mathrm{i}$ obiteljskog života. ${ }^{96}$

S tim u vezi možemo navesti Willisov zaključak da se neovisno o navedenoj karakterizaciji ovakvih sankcija, makar to bilo i od strane VSUN-a, pri njihovoj primjeni moraju poštovati procesna prava pojedinaca $\mathrm{i}$ entiteta protiv kojih su usmjerene, s obzirom na težinu posljedica koje one nose sa sobom. ${ }^{97}$

Dakle, bilo bi nezahvalno jednoznačno odrediti ove sankcije kao mjere kaznenog ili administrativnoga karaktera. Riječ je o mjerama sui generis koje karakterizira njihova preventivna narav, nužna ograničenja procesnih prava s obzirom na učinak iznenađenja u njihovoj primjeni te teške posljedice njihove primjene.

Također je moguće postaviti i pitanje je li VSUN uopće vezan, pri postupanju, procesnim pravilima, odnosno je li obvezan poštovati prava osoba, odnosno entiteta prema kojima se primjenjuju sankcije.

Pravilo je da su međunarodne organizacije vezane međunarodnim pravnim pravilima relevantnima za njihovo djelovanje, svrhe i ovlasti. ${ }^{98}$

U presudi Reparations case Međunarodnog suda, Sud je utvrdio da su Ujedinjeni narodi subjekt međunarodnog prava, sposobni biti nositeljem međunarodnih prava i obveza, ali i da ta prava i obveze ovise o njihovoj svrsi i funkciji, kako proizlazi iz njihovih konstitutivnih dokumenata i dokumenata nastalih njihovom praksom. ${ }^{99}$ Sukladno tomu, iako u Povelji UN-a tako nije izrijekom propisano, VSUN, pri provođenju svojih akcija, može biti vezan međunarodnim običajnim pravom i općim načelima prava, baš kao i svi drugi subjekti međunarodnog prava. ${ }^{100}$

U predmetu Conditions of Admission Case, Međunarodni sud je utvrdio da politička narav tijela ne može to tijelo osloboditi obveze pridržavanja odredbi ugovora koji su uspostavili Ujedinjeni narodi kad one nameću ograničenja njegovim ovlastima. ${ }^{101}$ Isto tako, u predmetu Certain Expenses Case, Međunarodni sud je utvrdio da ovlasti VSUN-a nisu neograničene, ali da se, kad je njegovo djelovanje potrebno u cilju održavanja međunarodnog mira i sigurnosti, mora presumirati da

95 Mišljenje nezavisnog odvjetnika Bota C584/10 P, C593/10 P i C595/10 P, ECLI:EU:C:2013:176 (u daljnjem tekstu Mišljenje Kadi IV), para. 68.

96 Presuda od 18.7.2013. Europska komisija i dr. protiv Yassin Abdullah Kadi, spojeni predmeti C-584/10 P, C-593/10 P i C-595/10 P, ECLI:EU:C:2013:518 (dalje u tekstu Kadi IV), para. 132.

97 Willis, op. cit. u bilj. 7, str. 25. Vidi i Eckes, C., Decision making in the Dark? Autonomous EU Sanctions and National Classification, Amsterdam Centre for European Law and Governance, University of Amsterdam Research Paper No. 2012-02, June 4. 2012., str. 23.

98 Willis, op. cit. u bilj. 7, str. 27. Vidi i Ghasem Zamani i Mazaheri op. cit. u bilj. 91, str. 227.

99 Reparations for Injuries, Advirsory opinion, 1949 ICJ, 179. i 180., http://www.icj-cij.org/files/ case-related/4/004-19490411-ADV-01-00-EN.pdf (posljednji pristup 6.7.2018.).

100 Willis, op. cit. u bilj. 7, str. 32.

101 Conditions of Admission of State to Membership in the United Nations, Advirsory Opinion 1948, 64. http://www.icj-cij.org/files/case-related/3/003-19480528-ADV-01-00-EN.pdf (posljednji pristup 6.7.2018.). 
ono ne ide ultra vires. ${ }^{102}$ Spomenuta ograničenja, prema Willisu, mogu proizlaziti iz Povelje UN-a, ius cogens, pojedinih sporazuma, običajnog prava i općih načela prava.

Dakle, opće je prihvaćeno da je VSUN vezan kategorijom ius cogens. Ovo je pravilo, između ostalog, ${ }^{103}$ postavio i sudac Lauterpacht u svojem odvojenom mišljenju prilikom čega je konstatirao kako članak 103. Povelje UN-a ne može dati rezolucijama VSUN-a prednost pred ius cogens. ${ }^{104}$ Ovakav položaj ius cogens konstatirali su i neki regionalni sudovi, kao što je i Sud EU u predmetu Kadi I, ali i, primjerice, Švicarski savezni sud. ${ }^{105}$

\section{ZAKLJUČNA RAZMATRANJA}

Sustav sankcija VSUN-a znatno se razvijao u posljednjih petnaestak godina te pod utjecajem kritika evoluirao u smjeru ostvarivanja sve veće zaštite prava pravnih $i$ fizičkih osoba prema kojima se primjenjuju sankcije.

Tako je početak tog razvoja označavala odsutnost bilo kakvog nadzornog mehanizma nad provođenjem sankcija te nepostojanje bilo kakve zaštite prava navedenih osoba. Postupno, sustav sankcija VSUN-a uklanjao je vlastite nedostatke. U tom smislu, kao važnije rezolucije, odnosno njima uvedene promjene mogu se navesti Rezolucija 1390 (2002), koja se zalaže za veći stupanj transparentnosti, Rezolucija 1452 (2002), koja predviđa određene iznimke od primjene mjera iz prethodnih rezolucija s ciljem omogućavanja zadovoljavanja osnovnih potreba osoba prema kojima se primjenjuju sankcije, Rezolucija 1617 (2005), koja prvi put daje svojevrsnu definiciju ,povezanosti“" s Al-Qaidom, Osamom bin Ladenom i talibanima, Rezolucija 1730 (2006), koja uspostavlja središnju točku, koja će primati zahtjeve za brisanje s Liste i ispunjavati druge zadatke te Rezolucija 1904 (2009), kojom je ustanovljen Ured pravobranitelja, kao i njezine sljedbenice koje su ojačavale ovlasti pravobranitelja.

Ovakav razvoj, između ostalog, rezultat je i kritika koje je uputio Sud EU-a.

Tako je u presudi Kadi II Sud konstatirao da je bez obzira na postojanje središnje točke postupak pred Odborom 1267 u biti diplomatskog i međuvladinoga karaktera, a osobe i subjekti u pitanju nemaju stvarnu mogućnost zaštititi svoja prava. ${ }^{106}$ Po donošenju ove presude, došlo je do formiranja Ureda pravobranitelja, kao i postupnog jačanja njegovih ovlasti, no Opći je sud u presudi Kadi III konstatirao da sve ono što je naveo Sud u predmetu Kadi II u odnosu na središnju točku zapravo vrijedi i za Ured pravobranitelja te da VSUN još uvijek nije ustanovio nezavisno i nepristrano tijelo

102 Certain Expenses of the United Nations Advirsory Opinion 1962 ICJ, 168. http://www.icj-cij. org/files/case-related/49/049-19620720-ADV-01-00-EN.pdf (posljednji pristup 6.7.2018.).Vidi i Willis, op. cit. u bilj. 7, str. 37.

103 Willis, op. cit. u bilj. 7, str. 38-44.

104 Izdvojeno mišljenje suca Lauterpacha, Application of the Convention on the Prevention and Punishment of the Crime of Genocide, para. 100, http://www.icj-cij.org/files/caserelated/91/091-19930913-ORD-01-05-EN.pdf (posljednji pristup 6.7.2018.).

Willis, op. cit. u bilj. 7, str. 39.

105 Genser, Barth, op. cit. u bilj. 32, str. 13.

106 Kadi II, op. cit. u bilj. 89, para. 323. 
nadležno za saslušanje i odlučivanje o tužbama protiv pojedinačnih odluka Odbora 1267.

Zaštita prava osoba, odnosno entiteta prema kojima se primjenjuju sankcije svakako je načelo o kojem se mora voditi računa pri primjeni navedenih sankcija. Međutim, jednako tako mora se voditi računa i o posebnostima ovih sankcija s jedne strane te njihovu cilju. Kada je riječ o posebnostima, to su njihova preventivna narav, nužna ograničenja određenih procesnih prava te teške posljedice njihove primjene. Njihov je cilj spriječiti financiranje terorističkih grupa i njihovih aktivnosti.

S obzirom na uspostavu Ureda pravobranitelja, kao i njegove ovlasti, možda se ne može reći da je razina zaštite procesnih prava osoba, odnosno entiteta prema kojima se sankcije primjenjuju unutar sustava sankcija VSUN-a na zadovoljavajućoj razini, ali se može konstatirati da je na najboljem putu prema tomu.

\section{LITERATURA}

\section{Knjige i članci}

1. Derenčinović, D., Ogledi o terorizmu i antiterorizmu, Pravni fakultet, Zagreb, 2005.

2. Derenčinović, D., Suvremeni antiterorizam na raskrižju - kaznenopravna reakcija vs. rat protiv terorizma, u: Derenčinović, D., Novi obzori suvremenog terorizma i antiterorizma, hrvatsko motrište, Pravni fakultet, Akademija pravnih znanosti Hrvatske, Zagreb, 2007.

3. Eckes, C., Decision making in the Dark? Autonomous EU Sanctions and National Classification, Amsterdam Centre for European Law and Governance, University of Amsterdam, Research Paper No. 2012-02, June 4. 2012.

4. Eckert, S., Biersteker, T., Due Process and Target Sanctions, An Update of the Watson Report, Watson Institute for International Studies, 2012.

5. Genser, J., Barth, K., When Due Process Concerns Become Dangerous: The Security Council's 1267 Regime and the Need for Reform, Boston College International and Comparative Law, vol. 33., br. 1., 2010.

6. Ghasem Zamani, S., Mazaheri J., The Need for International Judicial Review of UN Economic Sanctions u: Marossi, Z. A., Bassett M. R. Economic Sanctions under International Law, T.M.C. Asser press, Hague, 2015.

7. Ginsborg, L., Scheinin M, You Can't Always Get What You Want: The Kadi II Conundrum and the Security Council 1267 Terrorist Sanctions Regime, Essex Human Rights Review, vol. 8, br. 1, 2011, Special Issue on Balancing Counter-Terrorism Efforts with Human Rights a Decade After 9/11.

8. Gutherie, P., Security Council Sanctions and the Protection of Individual Rights, New York University Annual Survey of American Law, vol. 60., br. 3.

9. Kokott, J., Sobotta, C., The Kadi Case-Constitutional Core Values and International LawFinding the Balance, European Journal of International Law, vol. 23., br. 4., 2012.

10. Marguiles, P., Aftermath of an Unwise Decision: The U.N. Terrorist Sanctions Regime After Kadi II, Amsterdam Law Forum, vol. 6, br. 2., 2014.

11. Oehmichen, A., UN-EU-Terrorist-Listing-Legal Foundations and Impacts, ZIS 9/2014, 412 (online unter www.zis-online.com/dat/artikel/2014_9_847.pdf) (posljednji pristup 7.6.2018.).

12. Pedić, Ž., Odnos međunarodnoga i europskoga okvira za suzbijanje terorizma, Zagrebačka pravna revija, Zagrebačka pravna revija, vol. 1, br. 1. 2012.

13. Tünde Huber, K., Rodiles, A., An Ombudsperson in the United Nations Security Council: a Paradigm Shift?, Universidad Nacional Autónoma de México-Instituto de Investigaciones 
Jurídicas. Anuario Mexicano de Derecho Internacional, Décimo Aniversario, 2012.

14. van den Herik, L., The Security Council's Targeted Sanctions Regimes: In Need of Better protection of the Individual, Leiden Journal of International Law, vol. 20, br.4., 2007.

15. Willis, G., Security Council Targeted Sanctions, Due Process and the 1267 Ombudsperson, From the Selected Works of Grant L Willis, 2010.

Presude Suda EU, Međunarodnog suda i Mišljenja nezavisnih odvjetnika:

1. Izdvojeno mišljenje suca Lauterpacha, Application of the Convention on the Prevention and Punishment of the Crime of Genocide, para 100, http://www.icj-cij.org/files/caserelated/91/091-19930913-ORD-01-05-EN.pdf

2. Mišljenje od 16.1.2008., C-402/05 P i C-415/05 ECLI:EU:C:2008:11

3. Mišljenje od 19.3.2013. C584/10 P, C593/10 P i C595/10 P, ECLI:EU:C:2013:176

4. Presuda od 3.9.2008. Yassin Abdullah Kadi i Al Barakaat International Foundation protiv Vijeća Europske unije i Komisije Europskih zajednica, spojeni predmeti C-402/05 P i C-415/05 ECLI:EU:C:2008:461

5. Presuda od 30.9.2010. Yassin Abdullah Kadi protiv Europske komisije, T-85/09, ECLI:EU:T:2010:418

6. Presuda od 18.7.2013. Europska komisija $i$ dr. protiv Yassin Abdullah Kadi, spojeni predmeti C-584/10 P, C-593/10 P i C-595/10 P, ECLI:EU:C:2013:518

7. Presuda od 15.11.2012., Stichting Al-Aqsa i Nizozemska Kraljevina protiv Vijeća Europske unije, C-539/10 P i 550/10 P, ECLI:EU:C:2012:711

8. Presuda od 11.7.2007., Jose Maria Sison protiv Vijeća Europske unije, T-47/03 DEP, ECLI:EU:T:2007:207

9. Presuda od 12.12.2006. Organisation des Modjahedines du people d'Iran protiv Vijeća Europske unije, T-228/02 ECLI:EU:T:2006:384

10. Presuda Međunarodnog suda Reparations for Injuries, Advirsory opinion, 1949 ICJ, 179. i 180., http://www.icj-cij.org/files/case-related/4/004-19490411-ADV-01-00-EN.pdf

11. Presuda Međunarodnog suda Conditions of Admission of State to Membership in the United Nations, Advirsory Opinion 1948, 64. http://www.icj-cij.org/files/case-related/3/00319480528-ADV-01-00-EN.pdf

12. Presuda Međunarodnog suda Certain Expenses of the United Nations Advirsory Opinion 1962 ICJ, 168., http://www.icj-cij.org/files/case-related/49/049-19620720-ADV-01-00EN.pdf

\section{Rezolucije VSUN-a}

1. Rezolucija 1267 (1999) http://www.un.org/ga/search/view_doc.asp?symbol=S/ RES/1267\%281999\%29

2. Rezolucija 1333 (2000) http://www.un.org/ga/search/view_doc.asp?symbol=S/ RES/1333\%282000\%29

3. Rezolucija 1363 (2001) http://www.un.org/ga/search/view_doc.asp?symbol=S/ RES/1363\%20\%282001\%29

4. Rezolucija 1373 (2001) http://www.un.org/en/sc/ctc/specialmeetings/2012/docs/ United\%20Nations\%20Security\%20Council\%20Resolution\%201373\%20(2001).pdf

5. Rezolucija 1390 (2002) http://www.un.org/ga/search/view_doc.asp?symbol=S/ RES/1390\%20\%282002\%29

6. Rezolucija 1452 (2002) http://www.un.org/ga/search/view_doc.asp?symbol=S/ RES/ $1452 \% 20 \% 282002 \% 29$

7. Rezolucija 1526 (2004) http://www.un.org/ga/search/view_doc.asp?symbol=S/ RES/1526\%20\%282004\%29 
8. Rezolucija 1566 (2004) http://www.un.org/ga/search/view_doc.asp?symbol=S/ $\mathrm{RES} / 1566 \% 20(2004)$

9. Rezolucija 1617 (2005) http://www.un.org/ga/search/view_doc.asp?symbol=S/ RES/1617\%20\%282005\%29

10. Rezolucija 1624 (2005) http://www.refworld.org/docid/468372832.html

11. Rezolucija 1699 (2006) http://www.un.org/ga/search/view_doc.asp?symbol=S/ RES/1699\%282006\%29

12. Rezolucija 1730 (2006) http://www.un.org/ga/search/view_doc.asp?symbol=S/ RES/1730\%282006\%29

13. Rezolucija 1735 (2006) http://www.un.org/ga/search/view_doc.asp?symbol=S/ RES/ $1735 \% 20 \% 282006 \% 29$

14. Rezolucije 1822 (2008) http://www.un.org/ga/search/view_doc.asp?symbol=S/ RES/1822\%20\%282008\%29

15. Rezolucija 1904 (2009) http://www.un.org/ga/search/view_doc.asp?symbol=S/ RES/1904\%282009\%29

16. Rezolucija 1988 (2011) http://www.un.org/ga/search/view_doc.asp?symbol=S/ RES/1988\%20\%282011\%29

17. Rezolucija 1989 (2011) http://www.un.org/ga/search/view_doc.asp?symbol=S/ RES/1989\%20\%282011\%29

18. Rezolucija 2082 (2012) http://www.un.org/ga/search/view_doc.asp?symbol=S/ RES/2082\%20\%282012\%29

19. Rezolucija 2083 (2012) http://www.un.org/ga/search/view_doc.asp?symbol=S/ RES/2083\%282012\%29

20. Rezolucija 2160 (2014) http://www.un.org/en/ga/search/view_doc.asp?symbol=S/ RES/2160\%282014\%29

21. Rezolucija 2161 (2014) http://www.un.org/ga/search/view_doc.asp?symbol=S/ RES/2161\%20\%282014\%29

22. Rezolucija 2170 (2015) http://www.un.org/en/ga/search/view_doc.asp?symbol=S/ RES $/ 2170 \% 282014 \% 29$

23. Rezolucija 2178 (2015) http://www.un.org/en/ga/search/view_doc.asp?symbol=S/ RES/2178\%20\%282014\%29

24. Rezolucija 2253 (2015) http://www.un.org/en/ga/search/view_doc.asp?symbol=S/ RES/2253\%282015\%29

25. Rezolucija 2368 (2017) https://www.un.org/sc/suborg/en/s/res/2368-\%282017\%29

\section{Pravni propisi}

1. Povelja UN-a „Narodne novine - Međunarodni ugovori”, br. 15/1993.

2. Pročišćene inačice Ugovora o Europskoj uniji i Ugovora o funkcioniranju Europske unije 2010/C 83/01 (Lisabonski ugovor) http://www.mvep.hr/custompages/static/hrv/files/ pregovori/111221-lisabonski-prociscena.pdf (posljednji pristup 7.6.2018.). 


\section{Stjepan Novak*}

Summary

\section{DEVELOPMENT OF THE SYSTEM OF SANCTIONS AGAINST NATURAL AND LEGAL PERSONS, GROUPS AND NON-STATE ENTITIES CONNECTED WITH TERRORISM IN THE LEGAL ORDER OF THE UNITED NATIONS FROM THE PERSPECTIVE OF THE COURT OF JUSTICE OF THE EUROPEAN UNION}

The United Nations Security Council's system of sanctions directed against persons and entities associated with terrorism has evolved over the years in the direction of ever greater protection of these persons and entities' procedural rights at the time of imposing sanctions on them. Namely, this system of sanctions was characterised by numerous shortcomings which for the most part amounted to a lack of respect for the procedural rights of the natural and legal persons on which sanctions are imposed. The protection of the rights of the persons and entities on which sanctions are imposed no doubt includes taking into account, upon their imposition, certain principles. However, these sanctions' peculiarities and aim must equally be taken into account. The former include the sanctions' preventive nature, the necessary restrictions of certain procedural rights and the far-reaching consequences of their imposition. The latter consists of preventing the financing of terrorist groups and their activities. By taking into account the peculiarities of these sanctions and eliminating their shortcomings as described, the UN Security Council's system of sanctions responded to criticism concerning violations of the said rights. Thus, with time and under the influence of, inter alia, the Court of Justice of the European Union, these shortcomings came to be eliminated or were at least mitigated precisely in order to satisfy the requirements for a greater degree of protection of the rights of the said persons. It is therefore to be expected that this trend will continue.

Keywords: United Nations Security Council's sanctions, United Nations Security Council's resolutions, procedural rights, Court of Justice of the European Union.

* Stjepan Novak, Ph. D., Ministry of the Interior of the Republic of Croatia, Ulica grada Vukovara 33, Zagreb; stjepannovak@gmail.com. 
Zussamenfassung

\section{ENTWICKLUNG VON SANKTIONEN GEGEN DIE MIT TERRORISMUS VERBUNDENEN NATÜRLICHE UND JURISTISCHE PERSONEN, PERSONENGRUPPEN ODER NICHTSTAATLICHE ORGANISATIONEN IN DER RECHTSORDNUNG VON VEREINTEN NATIONEN UND AUS DER PERSPEKTIVE DES GERICHTSHOFS DER EUROPÄISCHEN UNION}

Das System von Sanktionen des UN-Sicherheitsrats gegen die mit Terrorismus verbundenen Personen und Körperschaften hat sich bei derer Auferlegung seit Jahren in Richtung des immer größeren Schutzes der Verfahrensrechte dieser Personen und Körperschaften entwickelt. Dieses System von Sanktionen wurde nämlich durch große Mängel hinsichtlich der Missachtung der Verfahrensrechte von natürlichen und juristischen Personen, gegen die diese Sanktionen auferlegt werden, gekennzeichnet.

Bei dem Schutz der Rechte von Personen und Körperschaften, gegen die diese Sanktionen auferlegt werden, muss man den Grundsatz die Rechnung tragen, welcher bei der Auferlegung genannter Sanktionen anzuwenden ist. Ebenfalls muss man auch die Besonderheiten dieser Sanktionen und deren Ziel in Betracht ziehen. Wenn es sich um die Besonderheiten handelt, dann spricht man über die vorbeugende Natur dieser Sanktionen, die notwendigen Beschränkungen bestimmter Verfahrensrechte und schwere Konsequenzen ihrer Auferlegung. Das Ziel der Sanktionen ist es, die Finanzierung terroristischer Gruppen und ihrer Aktivitäten zu verhindern.

Der UN-Sicherheitsrat hat auf die Kritiken bezüglich der Missachtung von genannten Rechten beantwortet, indem er die Besonderheiten dieser Sanktionen in Betracht zog und die beschrieben Mängel beseitigte.

Diese Mängel wurden unter anderem auch durch den Einfluss des Gerichtshofs der Europäischen Union beseitigt oder wenigstens gemildert, mit dem Ziel der Erreichung immer größeren Schutzes der Rechte dieser Personen, weshalb auch zu erwarten ist, dass man mit solcher Entwicklung fortsetzen wird.

Schlüsselwörter: Sanktionen des UN-Sicherheitsrates, Resolutionen des UN-Sicherheitsrates, Verfahrensrechte, Gerichtshof der Europäischen Union. 
Riassunto

\section{LO SVILUPPO DEL SISTEMA DELLE SANZIONI CONTRO PERSONE FISICHE E GIURIDICHE, GRUPPI ED ENTITÀ NON GOVERNATIVE NELL'AMBITO DELL'ORDINAMENTO GIURIDICO DELLE NAZIONI UNITE VISTO DALLA CORTE DI GIUSTIZIA DELL'UNIONE EUROPEA}

Il sistema delle sanzioni del Consiglio di sicurezza delle Nazioni Unite orientato contro le persone ovvero le entità collegate al terrorismo nel corso degli anni s'è sviluppato nella direzione della sempre maggiore tutela dei diritti processuali di tali persone ovvero entità in occasione delle loro intrusioni. Precisamente, questo sistema di sanzioni è stato contraddistinto anche da un grande numero di lacune che erano perlopiù collegate al mancato rispetto dei diritti processuali delle persone fisiche e giuridiche nei confronti delle quali venivano comminate le sanzioni. La tutela dei diritti delle persone ovvero delle entità nei confronti delle quali vengono comminate le sanzioni certamente includono l'applicazione dei principi dei quali occorre tenere conto in occasione della comminazione delle sanzioni. Tuttavia, allo stesso modo va tenuto conto anche delle peculiarità di tali sanzioni e del fine che perseguono. Quando si tratta delle particolarità, queste sono: il loro carattere preventivo; la necessaria limitazione di determinati diritti processuali e le pesanti conseguenze della loro comminazione. Il loro scopo è quello di evitare il finanziamento dei gruppi terroristici e le loro attività. Tenendo conto delle peculiarità di queste sanzioni e colmandone le lacune poc'anzi descritte, il sistema delle sanzioni del Consiglio di sicurezza delle Nazioni Unite ha risposto alle critiche che si riferivano al mancato rispetto di detti diritti. Pertanto, tali lacune, tra l'altro anche sotto l'influenza della Corte di Giustizia dell'UE, con il tempo sono state colmate, o perlomeno sono diminuite, proprio al fine di soddisfare alle richieste volte ad un maggiore grado di tutela di tali persone e v'è da aspettarsi che tale sviluppo continui.

Parole chiave: sanzione del Consiglio di sicurezza delle Nazioni Unite, risoluzione del Consiglio di sicurezza delle Nazioni Unite, diritti processuali, Corte di Giustizia dell'Unione europea. 